\title{
A response to the perception of the severity of medical error and the level of clinical seniority
}

This article was published in the following Dove Press journal: Advances in Medical Education and Practice

\author{
Soma Farag \\ Medical Department at Imperial \\ College, London University, London, \\ UK
}

Correspondence: Soma Farag Medical Department at Imperial College. London University, Kensington, London SW7 2AZ, UK Email sf3015@ic.ac.uk

\section{Dear editor}

I read with interest the study by Khan and Arsanious ${ }^{1}$ which gave insight into the perception of the severity of medical errors of practitioners of different grades and believed that there is much to be gained from it. Medical error in the duration of one's career is inevitable. The General Medical Council (GMC) advocates a Duty of Candor, ${ }^{2}$ which means to be open and honest when medical errors occur. In order to successfully explain what went wrong to patients and their relatives or seniors, one should first acknowledge that one has made the error and have an accurate perception of how severe this was.

Khan and Arsanious ${ }^{1}$ highlighted that, depending on the grade, different consequences of medical errors were emphasized. Medical students focused on emotional/psychological consequences; in contrast, consultants less so, instead, focusing more on legal consequences. ${ }^{1}$ Furthermore, empathy was illustrated to be positively correlated with an increased error severity score, hinting at increased investment of the clinician in patients' care. However, a confounding factor is what participants constitute as an error in the first place: a corrected mistake so that no harmful consequences occur-i.e. a "never event" or an uncorrected one; where harm does occur. This highlights that open discussions should be held between medical team members during ward meetings to illustrate what page everyone is on. Despite this, the study showed that homogeneity in that perception was particularly based on the magnitude of consequences of the error.

In addition, rarer events were likely to be considered as errors compared to common ones, such as prescribing, by consultants compared to junior staff. ${ }^{1}$ Although the latter are likely to make prescribing errors compared to the former, ${ }^{3}$ this desensitization effect is still not desirable given that prescribing errors are costly and detrimental to patient care. ${ }^{3}$ Hence, schemes should be implemented to tackle these common errors. At Imperial College London, prescribing medication tutorials are commenced early in the curriculum during the third year, so that by sixth year medical students are better equipped. Other medical schools have implemented prescribing e-tutorials for their students. Catling et al showed that students who completed these modules had a significantly increased confidence across all prescribing skills $\mathrm{s}^{4}$, national, widespread implementation of this may be effective. Prescribing tutorials aimed at reflecting on and tackling common errors could also be given to foundation year doctors to increase the knowledge and expertise as prescription errors are costly and detrimental to patient care.

\section{Disclosure}

The author reports no conflicts of interest in this communication. 


\section{References}

1. Khan I, Arsanious M. Does the perception of severity of medical error differ between varying levels of clinical seniority? Adv Med Educ Pract. 2018. 2018(9):443-452.

2. GMC. Openness and honesty when things go wrong: The professional duty of candour. Available from: https://www.gmc-uk.org/ethicalguidance/ethical-guidance-for-doctors/candour---openness-and-honestywhen-things-go-wrong. Accessed June 22, 2018.
3. Lewis PJ, Ashcroft DM, Doman T, Taylor D, Wass V, Tully MP. Exploring the causes of junior doctors' prescribing mistakes: a qualitative study. $\mathrm{Br}$ J Clin Pharmacol. 2014;78(2):310-319.

4. Catling F, Williams J, Baker R. A prescribing e-tutorial for medical students. Clin Teach. 2014;11(1):33-37. 


\section{Authors' reply}

Iqbal Khan'

Meret Arsanious ${ }^{2}$

'Northampton General Hospital NHS Trust, Northampton, UK;

${ }^{2}$ Epsom and St Helier University Hospitals NHS Trust, London, UK

Correspondence: Iqbal Khan

Northampton General Hospital, Cliftonville, Northampton NNI 5BD,

UK

Tel +44776735 6309

Email lqbal.khan@ngh.nhs.uk

\section{Dear editor}

We would like to thank the colleague for the helpful comments and agree with the observation that there should be better communication between teams to ascertain individual perception of the severity of an error and its impact on the patient. Across the UK, there is much effort in training medical students and junior doctors to prevent all errors which especially includes prescribing errors.

\section{Disclosure}

The authors report no conflicts of interest in this communication.

Dove Medical Press encourages responsible, free and frank academic debate. The content of the Advances in Medical Education and Practice 'letters to the editor' section does not necessarily represent the views of Dove Medical Press, its officers, agents, employees, related entities or the Advances in Medical Education and Practice editors. While all reasonable steps have been taken to confirm the content of each letter, Dove Medical Press accepts no liability in respect of the content of any letter, nor is it responsible for the content and accuracy of any letter to the editor.

\section{Publish your work in this journal}

Advances in Medical Education and Practice is an international, peerreviewed, open access journal that aims to present and publish research on Medical Education covering medical, dental, nursing and allied health care professional education. The journal covers undergraduate education, postgraduate training and continuing medical education including emerging trends and innovative models linking education, research, and health care services. The manuscript management system is completely online and includes a very quick and fair peer-review system. Visit http://www.dovepress.com/testimonials.php to read real quotes from published authors.

Submit your manuscript here: http://www.dovepress.com/advances-in-medical-education-and-practice-journal 